\title{
УДК 004.942:378.14
}

Космінська Олександра Михайлівна, кандидат фізико-математичних наук, доцент кафедри інформаційних технологій Донецького державного університету управління

\section{КОНТРОЛЬ ЗНАНЬ СТУДЕНТІВ ЗА ДОПОМОГОЮ ТЕСТУВАННЯ}

\section{Анотація}

Розглянуто питання щодо контролю знань студентів за допомогою тестування, висвітлені основні проблеми, що виникають на цьому шляху. Запропоновано часткове розв'язання цих проблем за допомогою системи автоматичного тестування 3 урахуванням особливостей предметів, що пов'язані з вивченням інформаційних технологій.

Ключові слова: контроль знань, проблеми тестування, системи тестування.

Постановка проблеми. Успішне навчання інформаційних технологій значною мірою пов'язано з організацією контролю й перевірки знань студентів. У зв'язку з переходом освітніх програм на кредитно-модульну систему зростає обсяг самостійної роботи студентів, у такій ситуації викладач повинен більш ретельно підходити до проблеми контролю знань студентів.

Крім того, специфіка предметів, пов'язаних з інформаційними технологіями, вимагає набуття практичних навичок разом із теоретичними. Скоріш практичні навички більш бажані. Однак, провести опитування з практичних навичок усіх студентів дуже складно за короткий термін.

У вузівській практиці знайшли застосування різні види перевірки знань, але нині все більше викладачів орієнтується на тестування, як на простий, та дуже швидкий метод опитування. Тестові завдання стають частинами поточного та підсумкового контролю, а іноді повністю його заміщають. Студенти з цікавістю сприймають таке опитування, вважаючи його деякою мірою грою.

Проблематиці тестування присвячено багато робіт. Розглядались різні аспекти проблеми: історія, досвід інших країн [6, 10], специфічні труднощі, що пов'язані з використанням тестів під час підготовки спеціалістів різного профілю [1, 3, 7], питання мотивації студентів [2] тощо.

Менше уваги приділялось аспекту об'єктивності тестування як контролю знань. Тестування вважають самим об'єктивним методом контролю знань, бо воно виключає суб'єктивність перевіряючого. Але виявилось, що це не зовсім так. Наприклад, Гаджиєва І.Х., Абдурахманов А.А. зазначають у роботі [3]: “Слабые студенты пасуют перед большим количеством наукообразных неправильных ответов и сильно затрудняются вспомнить, узнать правильный ответ. Вследствие этого, они прибегают к случайной выборке и набирают достаточное для положительной оценки количество правильных ответов. “Сильные” студенты слишком ответственно подходят к каждому слову задания, долго размышляют над приведенными ответами, теряют время, начинают волноваться - в итоге низкий результат”. Проблематика “вгадування" розглядалась також у роботах Колгатіна О.Г. [7, 8].

Мета дослідження - оцінити об'єктивність тестування як методу контролю знань, та запропонувати автоматичну систему тестування, що враховує такі недоліки як вгадування та зубріння.

Для перевірки об'єктивності тестування проводилось пробне стандартне тестування для студентів перших-других курсів різних спеціальностей (“Фінанси”, “Облік та аудит”, “Менеджмент виробничий”, “Правознавство” та інших) протягом трьох років. Автор проаналізував результати тестування вибраних 1000 студентів за однією тематикою за допомогою стандартного тестування (рис. 1).

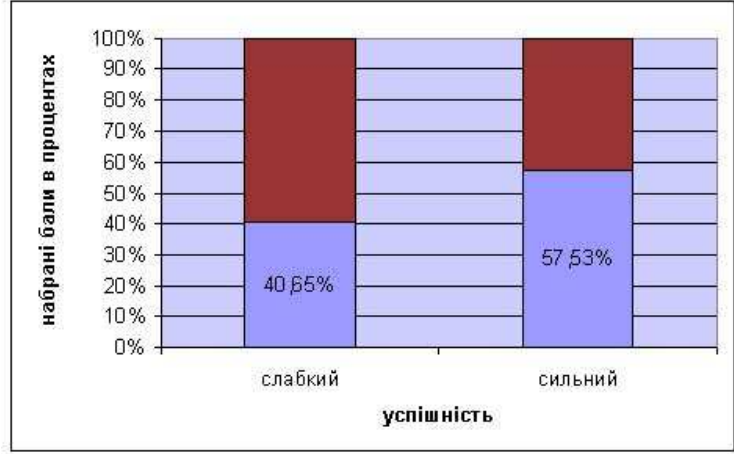

Рис. 1. Аналіз результатів стандартного тестування

На діаграмі вказані середні показники результатів «двійочників» (слабкий) та «відмінників» (сильний). Тобто слабкі студенти в середньому набирають понад $40 \%$ балів, тоді як відмінники менш ніж $60 \%$. Викладач, що не часто використовує тести у своїй практиці, може охарактеризувати такі результати різними причинами. Однак викладачів, що декілька років практикують тестову перевірку, не можна здивувати такими результатами - вони бачать їх після використання кожного тесту.

Що ми маємо: сильний студент навряд отримає свою оцінку, а слабкий може отримати “задовільно", зовсім не маючи уявлення про предмет. Стандартний тест не дає об'єктивної картини.

Тестування стає тільки контролюючим засобом, а, як відомо, уся діяльність викладача повинна нести навчальний характер. Майбутні фахівці на своєму робочому місці будуть розв'язувати реальні завдання, і життя не буде пропонувати альтернативні відповіді, як у тесті. У процесі бесіди з викладачем студент навчається, і якщо його знання поки що не зовсім чіткі, завдання викладача - його спрямувати: вказати майбутні шляхи.

Шляхи розв’язання - це вдосконалення методики тестування і, по-перше, відхід від альтернативних питань, які практично заполонили всі тестові завдання.

Для побудови тестових завдань використовується ціла низка методик, з яких найбільш придатними для автоматизації є:

- вибір варіанту (альтернативні);

- $\quad$ підбір пари; 
- заповнення пробілу;

- виключення зайвого.

Автором пропонується комплекс програм для контролю знань, що містить у собі базу завдань (питання 3 можливими відповідями) формату .mdb, програму контролю знань, базу результатів формату .mdb. База містить запитання різного характеру, що дозволяє більш об'єктивно оцінити знання. Це й альтернативні запитання, запитання з вибором декількох елементів, запитання на відповідність. Компонування запитань розроблене з орієнтацією на відповідну тематику - в даному випадку це робота в операційній системі Windows.

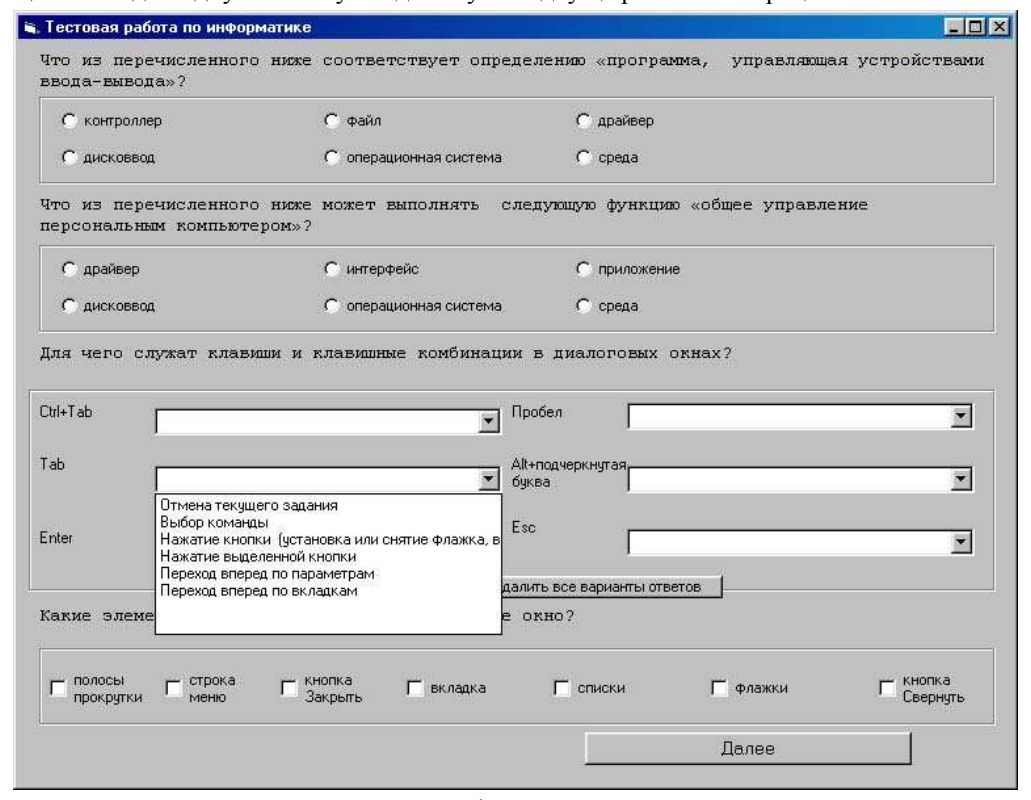

Рис. 2. Приклад вікна системи тестування

У процесі виконання студент, що тестується, може повернутися до будь-якого запитання, що часто відсутнє у стандартному тесті. Використання автоматичного обмеження на час дозволяє не затягувати процес перевірки. Крім того, відлік часу після реєстрації відбувається індивідуально, тобто кожний одержує однакову кількість часу. Доступ до програми контролю знань здійснюється тільки після реєстрації, що виключає можливість підміни результатів і повторного несанкціонованого проходження тесту.

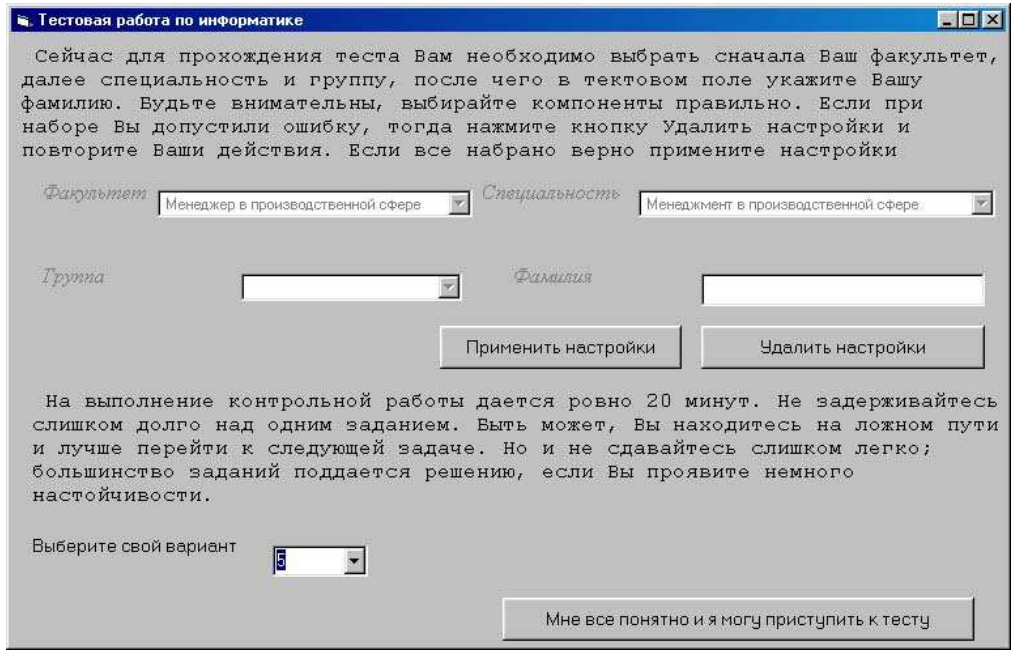

Рис. 3. Уведення даних студента, що тестується

У процесі роботи програми передбачені спливаючі підказки й попередження у разі виконання неправильних дій. Наприклад, якщо студент зовсім випадково вибирає закриття тесту або висновок результатів, то він буде проінформований про наслідки виконання своєї дії (рис. 4).

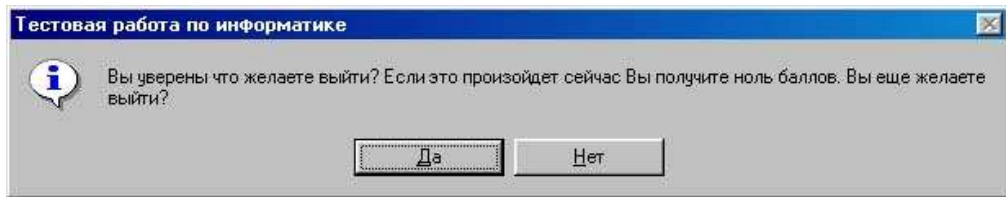

Рис. 4. Повідомлення системи

Програми, що входять до системи контролю знань, написані мовою програмування VB і призначені для роботи в операційній системі Windows.

Система контролю використовується в навчальному процесі під час проведення практичних і лабораторних робіт (визначення ступеня підготовки до заняття), самоконтролю студентів і для прийому заліків з курсів "Інформатика і комп'ютерна техніка", «Комп'ютерні мережі» і т. п.

База завдань системи контролю знань розбивається по варіантах і, відповідно, кожен студент одержує свої особисті завдання.

Дані за результатами зберігаються в базі даних, що дозволяє автоматично робити аналіз щодо сприйняття тематики групою студентів, дозв 


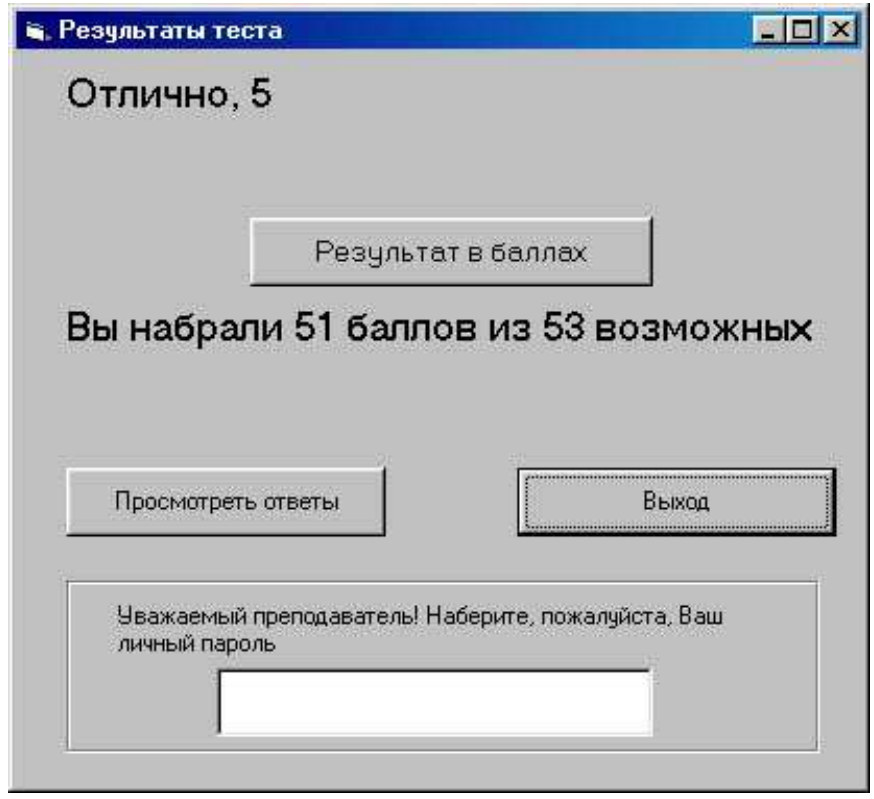

Рис. 5. Приклад видачі результатів з тестування

Крім зазначених особливостей програми, комплекс не заважає студенту користуватися можливостями доступу до системи, що фактично дає можливість отримати відповіді на запитання в процесі роботи із системою, тобто тестуватися й навчатися одночасно.

Результати перевірки знань тієї ж групи студентів за допомогою автоматизованої системи суттєво відмінні від попередніх, як видно з рис. $€$

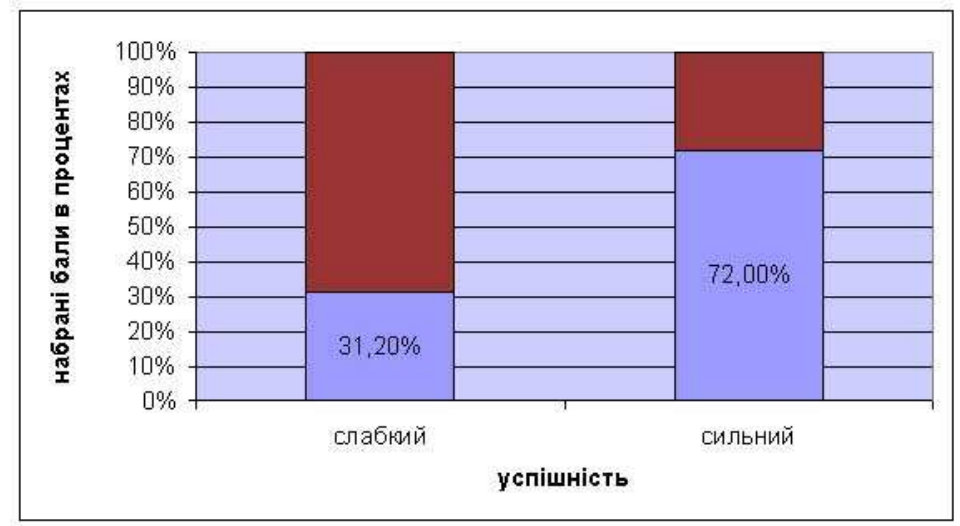

Рис. 6. Результати перевірки знань тематикою іншою системою

Висновки. Тестова перевірка знань, як доведено, не завжди об'єктивна. Тому використання тестів у всіх видах контролю, а особливо в підсу

Можлива часткова корекція тестової перевірки через її вдосконалення. Тести повинні містити різнопланові запитання, і тільки тоді перевір

Запропонована автором система дозволяє отримати об'єктивнішу оцінку знань студентів порівняно зі стандартним тестуванням, а також ви

Надалі можливе вдосконалення системи в напрямках використання для контролю знань студентів з інших дисциплін, а також специфічний

\section{Список використаних джерел}

1. Боднар П.М., Булах І.Є., Шило І.М. Роль комп'ютерного тестування в мотивації студентів при вивченні ендокринології. // Ендокринологія.- Т. 1. - 1996. - №2. - С. 114-117.

2. Булах І.Є., Шило І.М. Мотивація навчання і валідизація оцінювання рівня знань. //Педагогіка і психологія. Вісник АПН. - $1996 .-$ №3. - C. $125-129$.

3. Гаджиева И.Х., Абдурахманов А.А. К вопросу о контроле знаний студентов по физиологии растений// Вестник Башкирского университета. - 2001. - № 2 (II). - С. 145-146.

4. Гулюкина Н. А., Клишина С. В. Педагогический тест: этапы и особенности конструирования и использования: Учеб. пособие / Новосибирский гос. технический ун-т. - Новосибирск: Издательство НГТУ, 2001. — 132 с.

5. Касумова М. Ю. Тестирование - эффективный измеритель проверки знаний обучаемых // Мат. Х Междун. конф. "Применение новых технологий в образовании", 30 июня-3 июля 1999 г., Троицк.

6. Киринюк, А. А. Тестирование студентов как метод оценки качества образования /А. А. Киринюк. //Высшее юридическое образование. - Омск. - 2005. - С. 7-11.

7. Колгатін О.Г. Досвід впровадження автоматизованої системи діагностики навчальних досягнень 3 методів математичної статистики [Електронний ресурс] / В.Ю. Биков // Інформаційні технології і засоби навчання. - 2008. - №5. - Режим доступу: http://www.nbuv.gov.ua/ejournals/ITZN/em5/emg.html. - Заголовок з екрану.

8. Колгатін О.Г. Статистичний аналіз тесту з різними за формою завданнями // Засоби навчальної та науково-дослідної роботи./ За заг. ред. В.І. Свдокимова і О.М. Микитюка. - ХДПУ ім. Г.С.Сковороди. - Харків: ХДПУ, 2003. - Вип. 20. - С. 50-54.

9. Сайлер Б., Споттс Дж. Использование Microsoft Visual Basic 6. Специальное издание. - М.: Вильямс, 2005. - 832 с.

10. Чорна Н. В. Оцінювання навчальних досягнень учнів методом тестування в педагогіці США: Дис. ... канд. пед. наук: 13.00.01 / 
Вінницький держ. педагогічний ун-т ім. Михайла Коцюбинського. — Вінниця, 2005.

\section{КОНТРОЛЬ ЗНАНИЙ СТУДЕНТОВ ПРИ ПОМОЩИ ТЕСТИРОВАНИЯ \\ Косминская А.М. \\ Аннотация}

Рассмотрены вопросы контроля знаний студентов при помощи тестирования, освещены основные проблемы, которые возникают на этом пути. Предложено частичное решение этих проблем при помощи системы автоматического тестирования с учетом специфики предметов, связанных с информационными технологиями.

Ключевые слова: контроль знаний, проблемы тестирования, системы тестирования.

\section{CONTROL OF STUDENTS KNOWLEDGE THROUGH TESTING}

Kosminskay A.

\section{Resume}

Questions concerning the knowledge control of students through testing are considered, basic problems of testing are discussed. It is proposed the particulate decision of these problems trough the automatic testing system taking into account the features of «Information technologies» subject.

Keywords: knowledge control, problems of testing, testing system. 